\title{
Patterns of sialylation in differentiating rat decidual cells as revealed by lectin histochemistry
}

\author{
C. J. P. Jones ${ }^{1}$, J. D. Aplin ${ }^{2}$, J. Mulholland ${ }^{3}$ and S. R. Glasser ${ }^{3}$ \\ Departments of ${ }^{1}$ Pathological Sciences and ${ }^{2}$ Obstetrics and Gynaecology/Biochemistry and Molecular \\ Biology, University of Manchester, Manchester, UK; and ${ }^{3}$ Department of Cell Biology, Baylor \\ College of Medicine, Houston, TX 77030, USA
}

\begin{abstract}
Lectin histochemistry was used to demonstrate changes in the surface glycan distribution of uterine stromal cells as they differentiate to form decidual cells. Decidualization was induced in hormone-treated, ovariectomized rat uteri by needle scratch. Uterine tissue from days 2 to 8 of deciduoma development was examined with a panel of lectins specific for terminal nonreducing structures in $N$ - and $O$-linked classes of glycoprotein glycan, including $\alpha 2,3-$ and a2,6-linked sialic acid residues. Immunostaining for desmin was used to identify decidual cells. An increase in $N$-linked glycans associated with the cell surface and recognized by lectins from Phaseolus vulgaris (leukoagglutinin) (l-PHA), Pisum sativum (PSA) and Triticum vulgaris (WGA) was found during the early growth of decidual cells. As decidualization progressed regionally from the antimesometrial to mesometrial uterus, an increase in $\alpha 2,3$-linked sialic acid residues was followed by a loss of the $\alpha 2,6$-linked form. The results suggest that as stromal cells differentiate, glycoprotein biosynthesis and glycosyl transferase activity are altered. These changes in patterns of glycosylation may give rise to altered decidual cell-matrix and cell-cell interactions during differentiation and play a role in the modulation of decidual cell interactions with trophoblast during early placentation.
\end{abstract}

\section{Introduction}

After embryo attachment in the rodent uterus, stromal cells underlying the epithelial attachment site begin a process of differentiation known as decidualization, which was first described morphologically in the rat uterus by Krehbiel (1937). The first cells to differentiate form a cup-shaped area beneath the antimesometrial epithelium known as the primary decidual zone (PDZ). Differentiation then progresses deeper and laterally into the antimesometrial stroma to form the secondary decidual zone, and then subsequently into the mesometrial stroma where it forms the decidua basalis of pregnancy. Cells in the basal stroma, adjacent to the myometrium, do not differentiate.

The proposed functions of decidual cells have been reviewed (De Feo, 1967; Parr and Parr, 1989; Glasser, 1990) and probably include the provision of a physical environment conducive to placentation, allowing access of trophoblast to maternal blood, while regulating trophoblast invasion, modulation of the local immune system, paracrine and endocrine hormone secretion, and serving as a direct source of nutrients for embryos.

In rodents, decidualization can be induced in hormonally prepared animals by artificial stimuli. The uterine response to an artificial stimulus is termed a deciduoma and appears to be morphologically and biochemically identical to the decidua of pregnancy (O'Shea et al., 1983; Welsh and Enders, 1985; Glasser et al., 1987). Deciduoma can be used to study the effects of steroid hormones on stromal cell differentiation and to examine

Received 15 February 1993. this process in the absence of embryonic tissue. An optimal decidual response can be obtained by treating ovariectomized animals with a regimen of oestradiol and progesterone that mimics secretion of these hormones during the preimplantation period and then maintaining the induced decidual tissue by continued treatment with these hormones (Psychoyos, 1973). Decidualization in the antimesometrial stroma reaches a maximum 4 days after induction. As the mesometrial stroma begins to differentiate (5-6 days after induction), the antimesometrial tissue regresses (Bell, 1983; Hong et al., 1991). The deciduoma model has been used in this study to examine changes in the expression of lectin-binding molecules in differentiating stromal cells.

Although patterns of glycosylation are often sensitive indices of differentiative change in many tissues and have been extensively studied in epithelial cells of human and rodent endometrium (Glasser et al., 1988; Aplin, 1991), relatively little is known about glycosylation in the uterine stromal compartment. Changes in cell shape, cell-cell and cell-matrix interactions are striking during stromal cell decidualization and may be associated with modifications in cellular and extracellular oligosaccharides. We used lectin histochemistry to investigate changes in glycan distribution associated with the transformation of stroma to deciduoma. Expression of the intermediate filament protein desmin, an established marker for decidual cells (Glasser and Julian, 1986), was used to relate glycosylation patterns to decidual cell development. The main specificities of the lectins chosen are for terminal non-reducing structures in $\mathrm{N}$ - or $O$-linked classes of glycoprotein glycan which are more likely Downloaded from Bioscientifica.com at 04/26/2023 $09: 30: 01 \mathrm{AM}$
Fertility Ltd
via free access 
to be sensitive to differentiative events than are commonly expressed core structures. The panel includes two sialic acidbinding lectins that detect distinct linkage orientations (Shibuya et al., 1987; Taatjes et al., 1988; Wang and Cummings, 1988; Knibbs et al., 1991).

\section{Materials and Methods}

\section{Animals}

Virgin female Sprague-Dawley rats, 4 months old, were bilaterally ovariectomized and left untreated for 10 days to clear residual steroids from the circulation before beginning the following treatment schedule: oestradiol $\left(1 \mu \mathrm{g}\right.$ day $\left.^{-1}\right)$ for 2 days, no treatment for 2 days, progesterone $\left(2 \mathrm{mg} \mathrm{day}^{-1}\right)$ for 4 days, artificial stimulation of decidualization by scratching the length of one uterine horn antimesometrially with a 1.5-2 inch hypodermic needle with a barbed point on day 4 of progesterone treatment, and subsequent injection of progesterone $(2 \mathrm{mg})$ and oestradiol $(0.2 \mu \mathrm{g})$ once a day until the animals were killed. The unstimulated, contralateral uterine horn provided hormonally treated control tissue for each rat. At least three rats were examined at each time point.

\section{Tissue processing}

Rats were killed with a lethal i. p. injection of $5 \mathrm{ml}$ Avertin anaesthetic made with $2 \%$ tribromoethanol in $1 \%$ tertiary amyl alcohol (Sigma) on days 2-8 after decidual stimulation (day 0). Uterine horns were removed, trimmed free of fat and mesentery, and rinsed briefly in phosphate-buffered saline (PBS). Deciduomata and control tissues were fixed in a solution of $85 \%(\mathrm{v} / \mathrm{v})$ ethanol, $10 \%(\mathrm{v} / \mathrm{v})$ formalin and $5 \%(\mathrm{v} / \mathrm{v})$ acetic acid for $\mathrm{Ih}$ at room temperature, rinsed overnight in cold PBS, dehydrated through an ascending alcohol series and embedded in paraffin wax.

\section{Lectin histochemistry}

The lectins used were from Maackia amurensis (MAA), Sambucus nigra (SNA), Triticum vulgaris (WGA), Pisum sativum (PSA), Phaseolus vulgaris leuko-agglutinin (1-PHA) and Erythrina cristagalli (ECA) and were obtained from Sigma (Poole) except SNA and MAA which were from Boehringer Mannheim (Lewes). Their major sugar specificities are listed (Table I). Lectin histochemistry was carried out using the method of Jones et al. (1992a). Sections $(4 \mu \mathrm{m})$ were dewaxed in xylene, rinsed in absolute ethanol, and treated for $30 \mathrm{~min}$ with absolute methanol containing $0.4 \%(\mathrm{v} / \mathrm{v}) \mathrm{HCl}$ and $0.5 \%(\mathrm{v} / \mathrm{v})$ hydrogen peroxide to inactivate endogenous peroxidase. After rinsing in water and washing in Tris-buffered saline $\mathrm{pH} 7.6\left(50 \mathrm{mmol}\right.$ Tris- $\mathrm{HCl} \mathrm{l}^{-1}$, $0.15 \mathrm{~mol} \mathrm{NaCl} \mathrm{l}{ }^{-1}$; TBS) for $15 \mathrm{~min}$ (three changes), sections were incubated for $30 \mathrm{~min}$ at room temperature with $10 \mu \mathrm{g}$ biotinylated lectin $\mathrm{ml}^{-1}\left(50 \mu \mathrm{g} \mathrm{ml}^{-1}\right.$ for MAA) in TBS plus $1 \mathrm{mmol} \mathrm{CaCl} \mathrm{I}^{-1}, \mathrm{pH} 7.6$ (TBSC). Washing for $15 \mathrm{~min}$ in TBSC (three changes) was followed by incubation in $5 \mu \mathrm{g}$ avidinperoxidase $\mathrm{ml}^{-1}$ (Sigma) in $0.125 \mathrm{~mol}$ Tris- $\mathrm{HCl}{ }^{-1} \mathrm{pH} \mathrm{7.6}$, $0.347 \mathrm{~mol} \mathrm{NaCl}^{-1}$ (Jones et al., 1987) at room temperature for $1 \mathrm{~h}$. Sections were then washed in three changes of TBS over $15 \mathrm{~min}$. Sites of lectin binding were visualized using $0.05 \%$
Table 1. Lectins used in this study and their major specificities

\begin{tabular}{|c|c|c|}
\hline Lectin & Source & Major specificity \\
\hline MAA & Maackia amurensis & NeuNAc $\alpha 2,3$, Gal $\beta 1-$ \\
\hline SNA & $\begin{array}{l}\text { Sambucus nigra } \\
\text { Elderberry bark }\end{array}$ & NeuNAc $\alpha 2,6 \mathrm{Gal} / \mathrm{GalNAc-}$ \\
\hline WGA & $\begin{array}{l}\text { Triticum vulgaris } \\
\text { Wheatgerm }\end{array}$ & $\begin{array}{l}\text { Di- } N \text {-Acetylchitobiosyl and } \\
\text { some sialyl residues }\end{array}$ \\
\hline PSA & $\begin{array}{l}\text { Pisum sativum } \\
\text { Garden pea }\end{array}$ & $\begin{array}{l}\alpha \text {-D-Mannose in non-bisected } \\
\text { bi/tri-antennary, complex } \\
N \text {-linked sequences }\end{array}$ \\
\hline l-PHA & $\begin{array}{l}\text { Phaseolus vulgaris } \\
\text { (leucoagglutinin) } \\
\text { Kidney bean }\end{array}$ & $\begin{array}{l}\text { Tri/tetra-antennary non- } \\
\text { bisected complex } N \text {-linked } \\
\text { sequences }\end{array}$ \\
\hline $\mathrm{ECA}$ & $\begin{array}{l}\text { Erythrina cristagalli } \\
\text { Coral tree }\end{array}$ & Gal $\beta l, 4$ Glc $N A c \beta$ \\
\hline
\end{tabular}

$(w / v)$ diaminobenzidine tetrahydrochloride dihydrate (Aldrich Chemical Co., Gillingham) in TBS with $0.015 \%(\mathrm{v} / \mathrm{v})$ hydrogen peroxide for $5 \mathrm{~min}$ at room temperature. Sections were then washed, counterstained with methyl green, dehydrated, cleared and mounted in XAM neutral synthetic mounting medium (Gurr, BDH, Poole).

\section{Immunohistochemistry}

For the localization of desmin, sections were dewaxed, rinsed in ethanol and endogenous peroxidase activity was blocked as above. After rinsing in TBS, sections were incubated in mouse anti-desmin monoclonal antibody D33 (Dako, High Wycombe; I:50 in TBS) for $1 \mathrm{~h}$ at room temperature, washed in TBS, then incubated in peroxidase-conjugated rabbit anti-mouse $\operatorname{IgG}$ (Dako, 1:50 in TBS) for $1 \mathrm{~h}$. After washing, sections were treated with substrate, counterstained, dehydrated, cleared and mounted as described above.

\section{Histochemical controls}

As a negative control, sections were incubated in TBSC instead of the lectin or antibody. An internal positive control for desmin was provided by the presence of the myometrium which strongly expresses this protein.

Sections were stained with lectins in the presence of competing sugars; PSA in the presence of $0.1 \mathrm{~mol} \alpha$-methyl mannoside $\mathrm{l}^{-1}$ and ECA with added $0.05 \mathrm{~mol} N$-acetyl lactosamine $\mathrm{l}^{-1}$.

Sections were treated with $0.1 \mathrm{U}$ sialidase (neuraminidase, Sigma Type VI from Clostridium perfringens) in $0.2 \mathrm{~mol}$ acetate buffer $\mathrm{l}^{-1} \mathrm{pH} 5.5,1 \% \mathrm{CaCl}_{2}$ for $\mathrm{I} \mathrm{h}$ at $37^{\circ} \mathrm{C}$ before incubation in MAA or SNA.

As a further positive control, sections were treated with concanavalin $\mathrm{A}$, which recognizes mannose residues in a variety of common $N$-linked core structures.

\section{Results}

In this study, descriptions of lectin binding are limited to the resident stromal cells and their associated extracellular matrix; Downloaded from Bioscientifica.com at 04/26/2023 09:30:01AM 

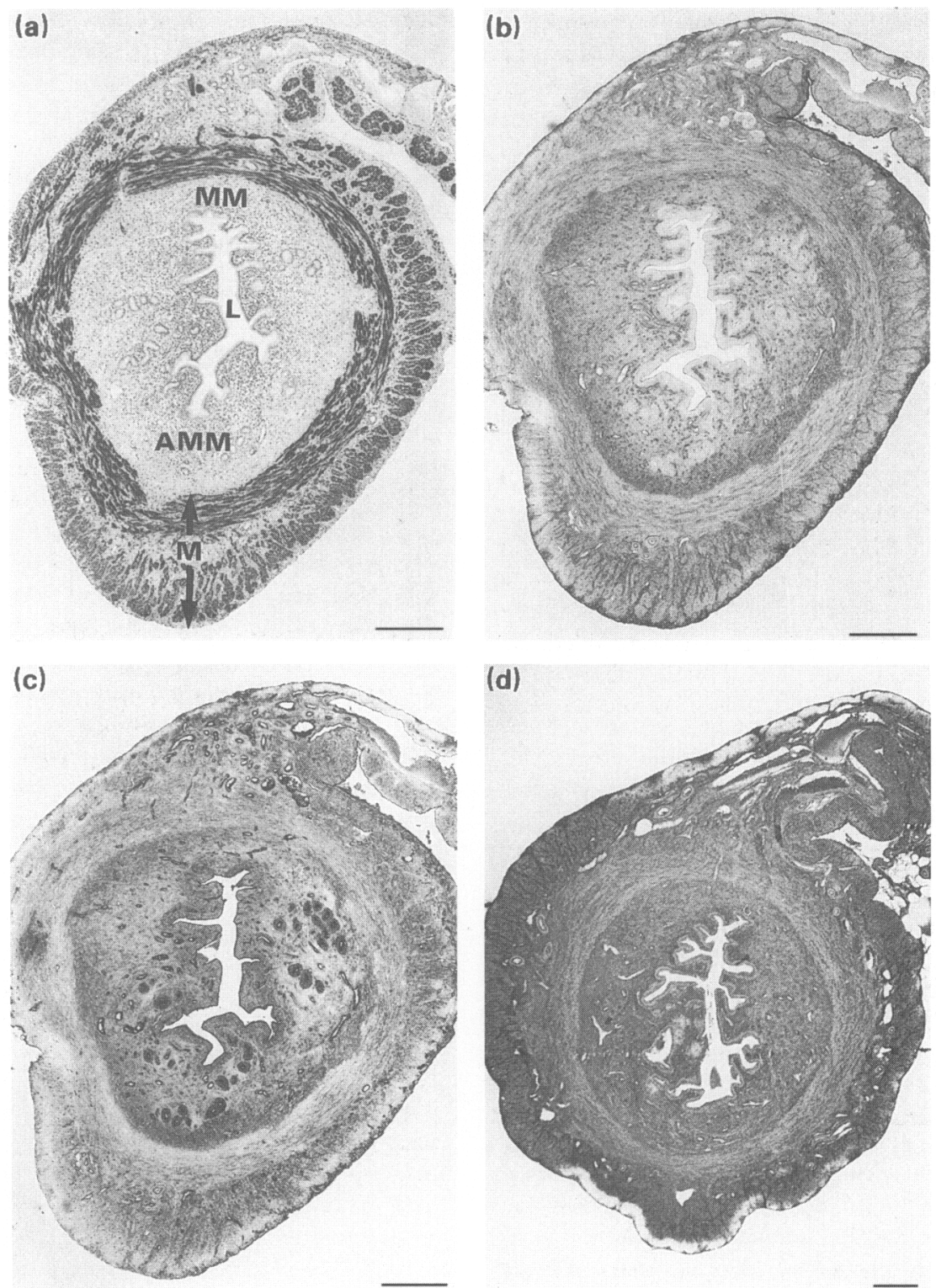

Fig. 1. Control rat uterus, unstimulated horn. (a) Desmin staining is restricted to the longitudinal and circumferential muscle layers of the myometrium (M), whereas the endometrial stroma is negative. MM: mesometrial stroma; AMM: antimesometrial stroma; L: lumen. (b) Lectin from Maackia amurensis (MAA) binds weakly to the endometrial stroma, with slightly increased staining in the basal regions. (c) Lectin from Sambucus nigra (SNA) shows moderate staining, especially in subluminal and basal regions of the endometrium, with the intermediate area exhibiting weaker binding. (d) Lectin from Pisum sativum (PSA) binds uniformly and intensely to the endometrial stroma. Scale bar represents $200 \mu \mathrm{m}$.

results of luminal and glandular epithelium, endothelial cells, bone-marrow derived cells and the myometrium are not reported.

\section{Control uterus, unstimulated horn}

Desmin staining was restricted to the myometrium (Fig. 1a). Stromal cells and extracellular matrix in all regions exhibited weak binding of MAA (Fig. 1b), whereas SNA bound more strongly to subluminal and basal regions than to the central area
(Fig. Ic). There was strong binding of PSA (Fig. Id), moderate binding of WGA, and weak binding of I-PHA and ECA, the latter being hardly detectable (see Table 2).

\section{Day 2 deciduoma}

Two days after the decidualizing stimulus, there was slight stromal cell enlargement in the primary decidual zone and some cells began to express detectable amounts of desmin. MAA bound more strongly to these cells than to the rest of the 
Table 2. Intensity of lectin staining in the rat uterus (day 4)

\begin{tabular}{|c|c|c|c|c|}
\hline \multirow[b]{3}{*}{ Lectin } & \multicolumn{2}{|c|}{ Decidualized uterus } & \multirow{2}{*}{\multicolumn{2}{|c|}{ Control uterus }} \\
\hline & \multirow{2}{*}{$\begin{array}{l}\text { Primary } \\
\text { decidua } \\
(\mathrm{PDZ})\end{array}$} & \multirow[b]{2}{*}{$\begin{array}{l}\text { Secondary } \\
\text { decidua }\end{array}$} & & \\
\hline & & & $\begin{array}{l}\text { Subluminal } \\
\text { stroma }\end{array}$ & $\begin{array}{c}\text { Basal } \\
\text { stroma }\end{array}$ \\
\hline MAA & ++ & + (wings ++ ) & \pm & + \\
\hline SNA & - & $++t$ & $\bar{t}$ & $+t$ \\
\hline WGA & +++ & ++ & ++ & ++ \\
\hline PSA & +++ & ++ & +++ & +++ \\
\hline l-PHA & +++ & + & \pm & \pm \\
\hline $\mathrm{ECA}$ & ++ & - & - & \pm \\
\hline
\end{tabular}

- , negative; \pm , very weak; + , weak; ++ , moderate; +++ , strong. MAA from Maackia amurensis; SNA from Sambucus nigra; WGA from Triticum vulgaris; PSA from Pisum sativum; 1-PHA from Phaseolus vulgaris (leukoagglutinin); and ECA from Erythrina cristagalli.

stroma; this staining was, however, still faint and was almost completely removed by sialidase treatment.

Cells in the primary decidual zone bound SNA weakly and even lower amounts of binding were evident in the surrounding subjacent stroma. As in the control horn, the basal stroma was more strongly stained than was the subluminal stroma. This staining was also removed by sialidase treatment.

When compared with nondifferentiated stromal cells, decidual cells gave increased reactivity with WGA, PSA and 1-PHA. This was particularly evident with l-PHA, as its binding was mainly restricted to the area of decidualization. There was virtually no binding of ECA in the stroma on day 2 (data not shown).

\section{Day 3 deciduoma}

Considerable cellular proliferation and enlargement was evident in the primary decidual zone which exhibited intense desmin immunoreactivity (Fig. 2a). Immediately beneath the lumen, a narrow band of desmin-containing cells two to three cells thick extended from the primary decidual zone towards the mesometrial pole. Moderate MAA staining was evident throughout the stroma (Fig. $2 \mathrm{~b}$ ) and this was labile to sialidase treatment. Close examination revealed surface staining of the cells which could be resolved into fine processes or fibrils extending across the intercellular spaces (not shown).

SNA reactivity was similar to that seen on day 2 , with moderate staining throughout the stroma (Fig. 2c), weaker binding in the subluminal stroma but slightly stronger reactivity in the primary decidual zone. Sialidase removed all but a low level of residual binding in the primary decidual zone.

I-PHA staining was concentrated in the primary decidual zone and in a narrow band of stroma immediately subjacent to the uterine lumen (Fig. 2d). Enhanced binding in the latter area was also observed using WGA (Fig. 2e) and PSA (Fig. 2f).

\section{Day 4 deciduoma}

The entire suprabasal antimesometrial sector of the stromal compartment was stained by antibody to desmin, with a narrow band of desmin-positive cells beneath the luminal epithelium again extending further towards the mesometrial pole (Fig. 3a). MAA now bound strongly to two discrete areas, or 'wings', of subluminal stromal cells located laterally and slightly displaced towards the antimesometrial pole (Fig. 3b), which partly coincided with desmin-weak areas. The primary decidual zone also showed moderate staining apart from a small area at the antimesometrial tip of the lumen, which expressed the highest concentration of desmin, and showed only weak MAA binding. Staining with MAA over the rest of the endometrium showed little difference from previous days.

There was a change in the SNA staining pattern of the primary decidual zone on day 4 , with a striking loss of binding in the primary decidual zone (Fig. 3c). The large and often binucleate cells exhibited a completely clear cytoplasm and no surface membrane staining (Fig. 3d). The zone of reduced SNA binding was much less extensive than the desmin-positive area. At the margins of the unstained area, intercellular heterogeneity was apparent, with strongly stained and unstained cells in close apposition (Fig. 3d). Decidual or undifferentiated cells in all other areas of the stroma showed moderate to strong staining with SNA, particularly on the cell surfaces and extracellular matrix. After sialidase treatment, most of this staining was lost.

At this stage, 1-PHA also strongly stained the two lateral MAA-positive 'wings' on each side of the lumen and the primary decidual zone (Fig. 3e). Staining with WGA and PSA continued to be strongest around the lumen and in the primary decidual zone (data not shown). ECA staining appeared for the first time in decidual tissue and was localized to the SNAnegative area of the primary decidual zone (Fig. 3f). Observations made on day 4 tissue and the time of maximal growth of the deciduoma are summarized (Table 2 ).

\section{Day 5 deciduoma}

At this stage, desmin-reactive cells occupied the entire antimesometrial half of the endometrium as well as a subluminal area of the mesometrial stroma (Fig. 4a). Lateral subluminal MAA binding was now much more extensive, with 'wings' of reactivity extending deeply into the stroma (Fig. $4 \mathrm{~b}$ ). Relative to day 4 , these had also migrated towards the mesometrial pole, thus progressing in advance of the onset of desmin expression in the secondary decidual zone. Cytoplasmic binding was slight or moderate but surface staining was extremely strong. In other areas of the endometrium staining was much weaker, although cell surfaces were still clearly delineated. Most endometrial MAA binding was abolished by pretreatment with sialidase, and a low level of residual staining was detectable in the 'wings' (Fig. 4c).

The area of low SNA reactivity now extended mesometrially on each side of the lumen and towards the myometrium (Fig. 4d). The large decidual cells showed some pale surface staining. The SNA-weak area encompassed desmin-positive cells (although by no means the whole desmin-positive population) and, except in a small region in the lateral subluminal stroma, did not overlap greatly with the MAA-strong cell population.

Stronger SNA binding was observed in the deeper antimesometrial stroma, with clearly defined intercellular boundaries. The smaller cells in the mesometrial segment were less distinctly delimited. Sialidase pretreatment greatly reduced the 

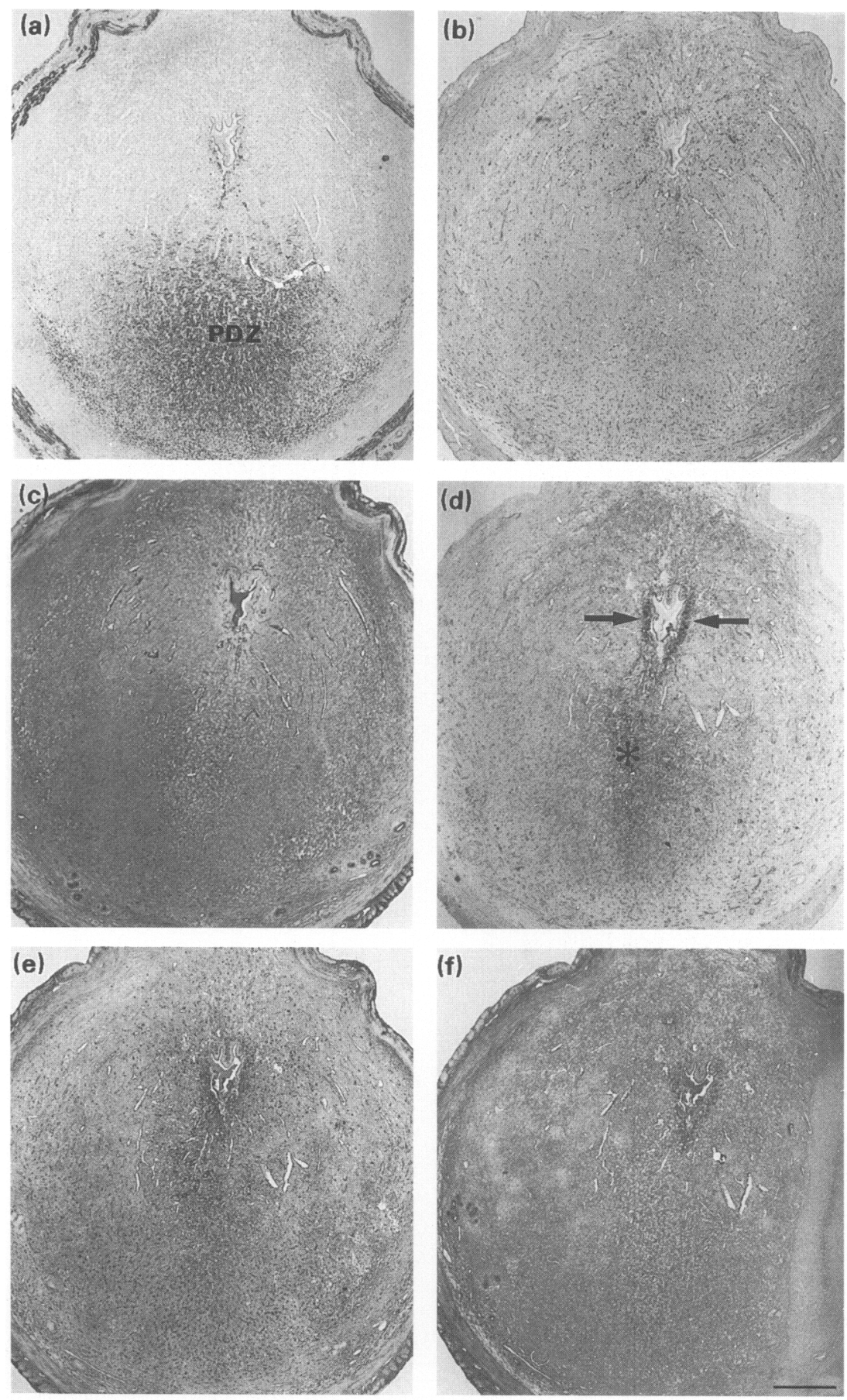

Fig. 2. Rat deciduoma, day 3. (a) Desmin reactivity is now intense in the primary decidual zone (PDZ). The mesometrial area is unstained. (b) Lectin from Maackia amurensis (MAA) stains moderately throughout the stroma. (c) Lectin from Sambucus nigra (SNA) binds moderately to the stroma, except in the area immediately beneath the lumen, where staining is weaker. (d) Lectin from Phaseolus vulgaris (l-PHA) binds strongly to the PDZ $\left(^{*}\right)$ and to the cells immediately beneath the lateral luminal epithelium (arrows). (e) Lectin from Triticum vulgaris (WGA) shows a pattern of binding somewhat similar to that seen with I-PHA. (f) Lectin from Pisum sativum (PSA) binds most strongly to the area of stroma immediately beneath the lumen, with moderate binding elsewhere in the stroma. Scale bar represents $400 \mu \mathrm{m}$. 

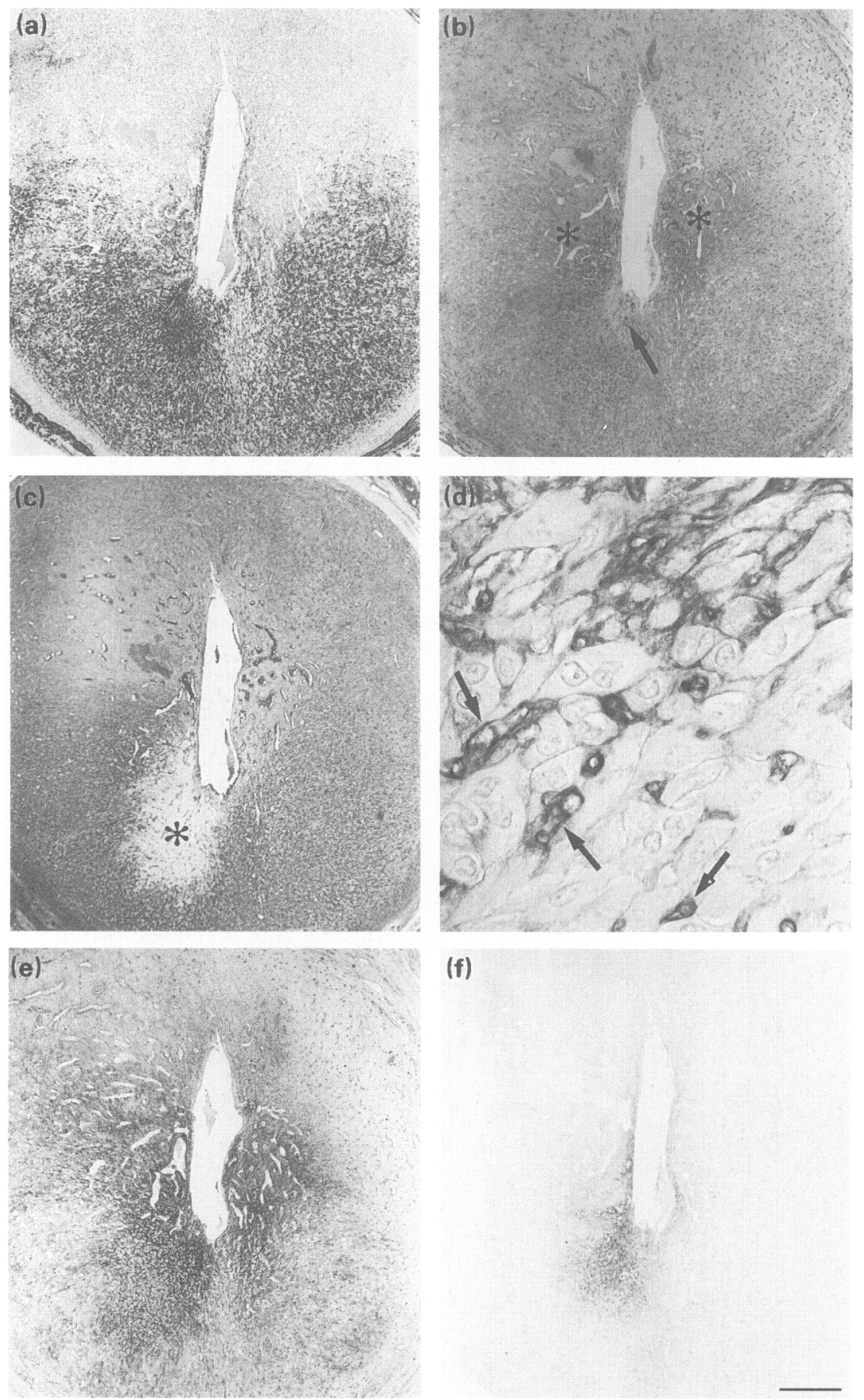

(f)

Fig. 3. Rat deciduoma, day 4. (a) Desmin reactivity is present in the whole antimesometrial suprabasal segment of the endometrium. (b) Staining by lectin from Maackia amurensis (MAA) is concentrated in two lateral 'wings' $\left(^{*}\right)$ with moderate binding elsewhere in the stroma apart from a small area at the antimesometrial tip of the lumen (arrow), which shows reduced activity and corresponds to a site of intense desmin expression. (c) Lectin from Sambucus nigra (SNA) shows a dramatic loss of binding in the primary decidual zone $\left(^{*}\right)$. (d) High power view of the interface between lectin from Sambucus nigra (SNA)-stained and unstained areas of tissue. Between the decidual cells, small deeply stained capillaries can be seen (arrows). The decidual cells in this area are clearly heterogeneous with respect to binding affinity for SNA. (e) l-PHA binds to the antimesometrial decidual cells beneath the uterine lumen as well as to lateral 'wings'. The rest of the endometrial stroma stains only lightly. ( $f$ ) ECA-positive cells correspond to those showing reduced SNA-binding in the primary decidual zone. Scale bar represents $400 \mu \mathrm{m}$ ( $a, b, c$, e and $f$ ) and $40 \mu \mathrm{m}$ (d). 

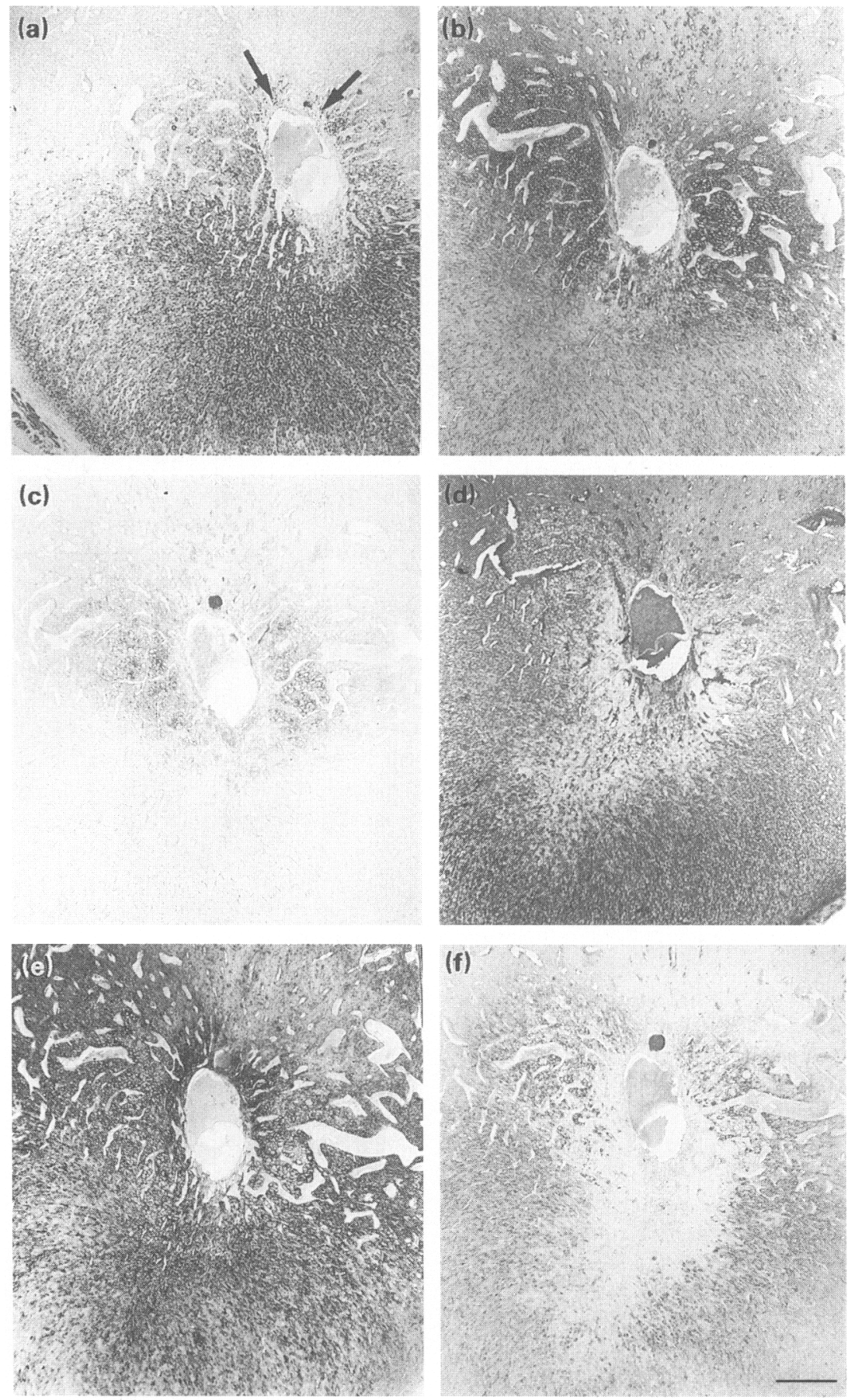

Fig. 4. Rat deciduoma, day 5. (a) Desmin staining now includes the whole antimesometrial decidua and the mesometrial subepithelial stroma (arrows). (b) Deeply staining 'wings' of reactivity with lectin from Maackia amurensis (MAA) can be seen on each side of the uterine lumen, approaching closer to the mesometrial pole than do the cells expressing desmin. (c) After sialidase pretreatment, most of the MAA binding is lost except for a residue visible in the lateral 'wings'. (d) Binding of lectin from Sambucus nigra (SNA) is present in deeper areas of the stroma, but a discrete area of weak binding can be seen beneath the uterine lumen, extending in a mesometrial direction; most of the affected (SNA-weak) cells do not greatly overlap with those binding MAA. (e) Binding of lectin from Phaseolus vulgaris (PHA) now includes most of the suprabasal endometrium, with a narrow mesometrial subluminal band staining particularly strongly. (f) The binding of SNA is partially labile to sialidase. Scale bar represents $400 \mu \mathrm{m}$. 
staining (Fig. 4f). 1-PHA binding on day 5 extended to nearly all of the endometrial stroma except the basal region (Fig. 4e). PSA and WGA also stained both decidualized and undifferentiated stroma, whereas ECA continued to bind to those regions showing a decrease in SNA affinity (data not shown).

\section{Day 6 deciduoma}

By day 6, cells expressing desmin occupied two-thirds of the stromal compartment and only a narrow band of basal tissue remained unstained along with the mesometrial segment. MAA binding, which as before was pericellular, extended to approximately one-third the depth of the endometrial stroma both antimesometrially and mesometrially. The deeper population of desmin-positive decidual cells remained weakly stained for MAA. Most of the staining was lost after sialidase treatment.

At the same stage, a shallow zone of cells, which did not bind SNA, extended almost completely around the lumen. Much of this area was also MAA and ECA positive. The deeper stroma was fairly uniformly stained, although the cell outlines were less distinct. There was faint cytoplasmic and moderate surface and matrix staining which in places appeared rather globular. The bulk of this staining was resistant to sialidase, and the loss of SNA binding following enzyme treatment occurred only in the area adjacent to the myometrium. WGA, PSA and I-PHA gave fairly uniform binding of moderate intensity throughout the endometrial stroma.

\section{Days 7 and 8 deciduoma}

Decidual cell regression, characterized by enlargement of intercellular spaces and loss of desmin staining, was evident in the primary decidual zone (Fig. 5a). On days 7 and 8 there was diffuse and patchy desmin staining in the mesometrial stroma.

On day 7, MAA bound strongly beneath the lumen (Fig. 5b). Cytoplasmic staining was strong and granular and intercellular boundaries were difficult to resolve. In deeper areas of stroma, cytoplasmic staining was reduced and cell surface staining clearer. By day 8, MAA staining was still mainly subluminal, but more mesometrially distributed. After sialidase treatment, the bulk of staining was removed in tissue from both days.

Intense and uniform binding of SNA appeared on day 7 over most of the tissue (Fig. $5 \mathrm{c}$ ). Cytoplasmic staining was granular and cell boundaries were difficult to define except in the basal stroma where cell surface and extracellular matrix staining was particularly intense and sialidase resistant. There was little change on day 8 , with staining over the entire endometrial stroma most of which was again sialidase-resistant.

WGA, PSA and I-PHA gave fairly uniform and strong staining patterns on both days, although WGA staining was slightly weaker at the mesometrial pole on day 7. I-PHA, like MAA, gave slightly stronger staining mesometrially on day 8. ECA staining again tended to be strongest subjacent to the lumen, with weak staining in other areas on day 7 (Fig. $5 \mathrm{~d}$ ), although by day 8 diffuse mesometrial staining was also evident (Fig. 5e).

\section{Histochemical controls}

The effect of sialidase treatment on MAA and SNA binding are described above. Substitution of TBSC or TBS for the lectin or antibody abolished the staining completely. Incubation of the lectins PSA and ECA in the presence of competing sugars prevented staining (Fig. 5f). All uterine stromal cells bound concanavalin A, which recognizes core mannosyl residues in $N$ linked structures, at all stages of decidualization. This provided a positive control throughout the study.

\section{Discussion}

Striking alterations in cell surface glycosylation during decidualization of the rat uterine stroma have been revealed in this study using lectin histochemistry. SNA binding in a subpopulation of desmin-expressing cells of the primary decidual zone is dramatically reduced $\mathbf{4}$ days after the induction of decidualization. As decidualization progresses, the SNAnegative area became more extensive and exhibited more ECA binding, suggesting that loss of $\alpha 2,6$-linked sialic acid residues may expose terminal $N$-acetyl lactosamines. During the same period, two laterally orientated subluminal regions, or 'wings', of decidual cells appeared which strongly bind MAA, and the size of these regions gradually increased during days 4-5 to involve tissue in the mesometrial segment of the endometrium. These cells also showed alterations in the $N$-glycan profile, as detected by greater l-PHA binding, perhaps indicating synthesis of new $N$-linked chains containing terminal $\alpha 2,3$-linked sialic acid residues. Although the loss of SNA binding sites could result from secreted sialidase activity, these results strongly suggest that alterations in glycoprotein biosynthesis and glycosyl transferase activity are occurring in stromal cells as they differentiate.

This is the first time that alterations in sialylation of decidual cells have been described, although a reduction in the number of sialyl residues resulting in a decrease in the net surface charge of both blastocysts and uterine epithelium during implantation has been reported in both rats and mice (Nilsson et al., 1973; Enders and Schlafke, 1974; Jenkinson and Searle, 1977; Hewitt et al, 1979; Nilsson and Hjertén, 1982; Morris and Potter, 1984). In human endometrial epithelium, progesterone stimulates a major increase in vesicles of the Golgi apparatus (Dockery et al., 1988) as well as the appearance of new sialoglycans during the implantation phase (Hoadley et al., 1990; Aplin, 1991). The expression of sialyl transferases can be regulated by glucocorticoids (Wang et al., 1990; Kolinska et al., 1990) and the data presented here suggest that sensitization of uterine cells by ovarian steroids may similarly prepare them for regionally specific alterations in sialyl transferase expression during decidualization.

The functional significance of the alterations in sialylation of the stromal cell surface as it differentiates into a decidual cell is not known. Sialic acid may serve to mask subterminal recognition structures (Lloyd, 1975), to modulate the affinity of interactions at other binding sites in the same molecule (as in neural cell adhesion molecule; Regan, 1991), or serve as an integral part of a glycan ligand for specific cell adhesion molecules (Crocker et al., 1991; Berg et al., 1992). There is considerable evidence to demonstrate that altered levels and types of sialylation occur in normal differentiation (Taatjes and Roth, 1990; Aplin, 1991; Regan, 1991; Jones et al., 1992b; Yang et al., 1992) and in pathological processes (Morgenthaler et al., 1990; Sata Downloaded from Bioscientifica.com at 04/26/2023 09:30:01AM 

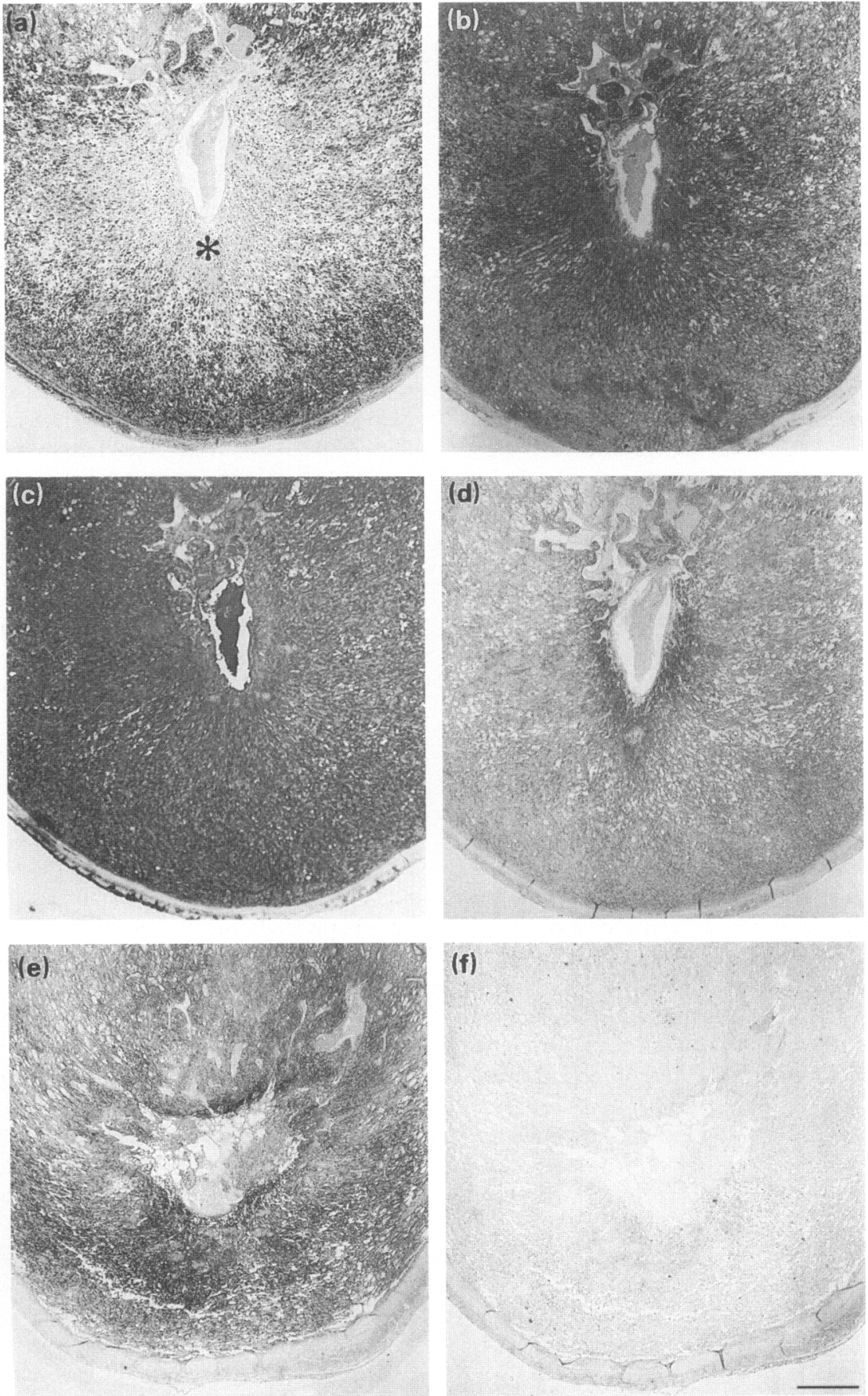

Fig. 5. Rat deciduoma, days 7-8. (a) On day 7, decidual cell regression is accompanied by loss of desmin staining, especially in the antimesometrial suprabasal area of the uterus $\left(^{*}\right.$ ). (b) Lectin from Mackia amurensis (MAA) stains most strongly around the subluminal region of the stroma, decreasing slightly in the basal areas. (c) Staining by lectin from Sambucus nigra (SNA) is generally uniform and intense. (d) Binding of lectin from Erythrina cristagalli (ECA) is present over most of the endometrium, but an area of strong staining is visible subjacent to the lumen, especially on the antimesometrial aspect. (e) ECA binding without and (f) with the presence of $0.05 \mathrm{~mol} \mathrm{~N}$-acetyl lactosamine $\mathrm{I}^{-\mathrm{I}}$ on day 8 . The competing sugar has eliminated the majority of the stain. Scale bar represents $400 \mu \mathrm{m}$. 
et al., 1991; Le Marer et al., 1992; Vandamme et al., 1992). The expression of sialyl $\alpha 2,3$-linkages has been associated with normal colonic mucosa, but malignant transformation is accompanied by the de novo expression of an $\alpha 2,6$-sialyltransferase, suggesting a relationship between $\alpha 2,6$ residues and cell growth (Sata et al., 1991). Greater numbers of sialyl $\alpha 2,6$-linked chain termini may also correlate with in vivo aggressiveness of malignant cells and cellular binding of collagen IV (Morganthaler et al., 1990). The reciprocal expression of $\alpha 2,3$ - and $\alpha 2,6$-linked sialic acid residues, which characterize stromal cell differentiation, may accordingly be related to the remodelling of the stromal extracellular matrix, which is a function of the decidual cell (Glasser et al., 1987; Aplin, 1991; Mulholland et al., 1992). The accumulation of various components of the extracellular matrix, such as collagen IV, laminin and heparan sulfate proteoglycan, and the loss of elements of the original matrix, such as collagen VI and fibronectin (Grinnell et al., 1982; Aplin, 1989; Glasser, 1990; Clark et al., 1992; Mulholland et al., 1992), are likely to be important to the interaction of trophoblast with the decidualizing stroma. However, the relationship of the shift from $\alpha 2,6$ - to $\alpha 2,3$-sialic acid residues on decidual cell surfaces and remodelling of the decidual extracellular matrix with trophoblast migration has not yet been determined.

In addition to changes in the accessibility and distribution of sialyl residues, there is an increase in several classes of $N$-linked glycan associated with the plasma membrane of decidualizing cells during their early period of growth and differentiation. The binding specificities of these lectins and the interpretations made from their histochemical behaviour have been discussed in detail elsewhere (Ball et al., 1989; Roberts et al., 1990). It is possible that these changes facilitate localized interactions between decidual cells and trophoblast that are required for the establishment of pregnancy (Bell, 1985; Aplin, 1991; Glasser et al., 1991). If the changes described above for deciduoma also occur in the uterus of the pregnant animal, as suggested by pilot studies on mice in our laboratory, the loss of $\alpha 2,6$-linked sialic acid and the expression of $\alpha 2,3$-linked residues at the antimesometrial primary decidual zone and underlying stroma should coincide with the decidual cell reaction which follows attachment of the mural trophoblast. The progressive development of the egg cylinder from the point of original attachment at the antimesometrial pole to the mesometrial locus is, therefore, coordinated with the regional evolution of the decidual cell reaction both morphologically and with respect to sialylation.

Variation in the lectin binding properties of differentiating stromal cells suggests a role for sialoglycans in decidual cell-cell interactions (Jollie and Bencosme, 1965; Kleinfeld et al., 1976; O'Shea ef al., 1983; Welsh and Enders, 1985; Parr et al., 1986). The increase in intercellular contact that follows the loss (O'Shea et al., 1983) and remodelling of the extracellular matrix (Mulholland et al., 1992) suggests that decidual cell-cell interactions may play a determinative role both at the sites of interaction with developing trophoblast and deeper in the differentiating stromal compartment. Reduction in the intercellular spaces is accompanied by the appearance of electron-dense, flocculent material (Brökelmann and Biggers, 1979; O'Shea et al., 1983; Parr et al., 1986). Changes in sialylation and the extracellular matrix may also effect reduction in intercellular space (Yang et al., 1992), and increase intercellular adhesion and communication between the maternal cells (Welsh and Enders, 1987).

The observations reported here also indicate that cells within the uterine stroma can exhibit differential responses to a deciduogenic stimulus. Differences among responsive cells are evident in the bilateral pattern of MAA binding seen in antimesometrial deciduoma (days 8-9). Structural and functional heterogeneity of decidual cells in different regions of the uterus has been described in a number of studies and reviewed by Bell (1985). A striking example is the absence of a decidual response in stromal cells of the basal zone (Krehbiel, 1937; Parr and Parr, 1989). Mesometrial decidual cells fail to achieve the same ploidy $(>4 N)$ observed in the antimesometrial decidual cells and thus appear to comprise a separate population of differentiated cells (Sartor, 1980). Functional differences between these two populations of cell have also been emphasized by Jayatilak et al. (1989), who demonstrated that decidual luteotrophin is expressed in the antimesometrial but not in the mesometrial decidua 8-13 days after induction of decidualization.

The role of these alterations in the glycosylation of the decidual cell surface remains to be elucidated. Decidualization is a critical step in the initiation of placentation and the establishment of pregnancy. The observations described above suggest that regulation of sialyltransferase activity accompanies stromal cell differentiation and may play an important role in producing an appropriate cell surface and extracellular environment for placentation.

The authors are grateful to R. W. Stoddart for his generous advice on lectin histochemistry and critical reading of the manuscript, and to L. Hong for providing fixed tissue specimens. This research was supported in part by NIH grants HD22785 and HD07495 (to S. R. Glasser and J. Mulholland).

\section{References}

Aplin JD (1989) Cellular biochemistry of the endometrium. In Biology of the Uterus (2nd Edn) pp 89-129 Eds WP Jollie and RM Wynn. Plenum Medical, New York

Aplin JD (1991) Glycans as biochemical markers of human endometrial secretory differentiation Journal of Reproduction and Fertility 91 525-541

Ball RY, Stoddart RW, Jones CJP and Mitchinson MJ (1989) Saccharide expression on wounded endothelial cell monolayers in vitro Joumal of Cell Science 93 163-172

Bell SC (1983) Decidualization: regional differentiation and associated function Oxford Reviews of Reproductive Biology 5 220-271

Bell SC (1985) Comparative aspects of decidualization in rodents and humans: cell types, secreted products and associated function. In Implantation of the Human Embryo, pP 7I-122 Eds RG Edwards, JM Purdy and PC Steptoe. Academic Press, London

Berg EL, Magnani J, Warnock, RA, Robinson MK and Butcher EC (1992) Comparison of L-selectin and E-selectin ligand specificities: the L-selectin can bind the E-selectin ligands sialyl Lex and sialyl Lea Biochemical and Biophysical Research Communications 184 1048-1055

Brökelmann J and Biggers JD (1979) Studies on the development of cell contacts and of the intercellular matrix during decidualisation in the rat Archives of Gynecology 227 103-117

Clark DE, Hurst PR, Myers DB and Spears GF (1992) Collagen concentrations in dissected tissue components of rat uterus on days 6,7 and 8 of pregnancy Joumal of Reproduction and Fertility 94 169-175

Crocker PR, Kelm S, Dubois C, Martin B, McWilliam AS, Shotton DM, Paulson JC and Gordon S (1991) Purification and properties of sialoadhesin, a sialic acid-binding receptor of murine tissue macrophages EMBO Journal 10 1661-1669

Downloaded from Bioscientifica.com at 04/26/2023 09:30:01AM 
De Feo VJ (1967) Decidualization. In Cellular Biology of the Uterus, pp 311-318 Ed RM Wynn. Appleton-Century-Crofts, New York

Dockery P, Li TC, Rogers AW, Cooke ID and Lenton EA (1988) The ultrastructure of the glandular epithelium in the timed endometrial biopsy Human Reproduction 3 826-834

Enders AC and Schlafke S (1974) Surface coats of the mouse blastocyst and uterus during the pre-implantation period Anatomical Record $18031-46$

Glasser SR (1990) Biochemical and structural changes in uterine endometrial cell types following natural or artificial deciduogenic stimuli Trophoblast Research 4 377-416

Glasser SR and Julian JA (1986) Intermediate filament protein as a marker for uterine stromal cell differentiation Biology of Reproduction 35 463-474

Glasser SR, Lampelo S, Munir MI and Julian JA (1987) Expression of desmin, laminin and fibronectin during in situ differentiation (decidualization) of rat uterine stromal cells Differentiation 35 132-142

Glasser SR, Julian JA, Decker GL, Tang J-Y and Carson DD (1988) Development of morphological and functional polarity in primary cultures of rat uterine epithelial cells Journal of Cell Biology 107 2409-2423

Glasser SR, Mulholland J, Julian JA, Mani SK, Munir MI and Soares MJ (1991) Blastocyst-endometrial relationships: reciprocal interactions between uterine epithelial and stromal cells and blastocysts Trophoblast Research 5 221-280

Grinnell F, Head JR and Hoffpauir J (1982) Fibronectin and cell shape in vivo: studies on the endometrium during pregnancy Joumal of Cell Biology 94 597-606

Hewitt K, Beer AE and Grinnell F (1979) Disappearance of anionic sites from the surface of the rat endometrial epithelium at the time of blastocyst implantation Biology of Reproduction 21 691-707

Hoadley ME, Seif MW and Aplin JD (1990) Menstrual cycle-dependent expression of keratan sulphate in human endometrium Biochemical Journal $266757-763$

Hong L, Mulholland J, Chinsky JM, Knudsen TB, Kellems RE and Glasser SR (1991) Developmental expression of adenosine deaminase during decidualisation in the rat uterus Biology of Reproduction 44 83-93

Jayatilak PG, Purylar TK, Herz Z, Fazleabas A and Gibori G (1989) Protein secretion by mesometrial and antimesometrial rat tissue: evidence for differential gene expression Endocrinology 125 659-666

Jenkinson EJ and Searle RF (1977) Cell surface changes on the mouse blastocyst at implantation Experimental Cell Research 106 386-390

Jollie WB and Bencosme SA (1965) Electron microscopic observations on primary decidua formation in the rat American Journal of Anatomy 116 $217-236$

Jones CJP, Mosley SM, Jeffrey IJM and Stoddart RW (1987) Elimination of the non-specific binding of avidin to tissue sections Histochemical Joumal 19 264-268

Jones CJP, Morrison CA and Stoddart RW (1992a) Histochemical analysis of rat testicular glycoconjugates. 1 . Subsets of $N$-linked saccharides in seminiferous tubules Histochemical Journal 24 319-326

Jones CJP, Morrison CA and Stoddart RW (1992b) Histochemical analysis of rat testicular glycoconjugates. 2. $\beta$-galactosyl residues in $O$-and $N$-linked glycans in seminiferous tubules Histochemical Journal 24 327-336

Kleinfeld RG, Morrow HA and De Feo VJ (1976) Intercellular junctions between decidual cells in the growing deciduoma of the pseudopregnant rat uterus Biology of Reproduction 15 593-603

Knibbs R, Goldstein IJ, Ratcliffe RM and Shibuya N (1991) Characterization of the carbohydrate binding specificity of the leukoagglutinating lectin from Maackio amurensis Journal of Biological Chemistry 226 83-88

Kolinska J, Baudysova M, Zakostelecka M, Kraml J and Kadlecova L (1990) Regulation of sialylation of intestinal brush-border enzymes and of sialyltransferase activity in organ cultures by dexamethasone Biochemistry international 22 495-508

Krehbiel RH (1937) Cytological studies of the decidual reaction in the rat during pregnancy and in the production of deciduomata Physiological Zoology 10 $212-238$

Le Marer N, Laudet V, Svensson EC, Cazlaris H, Van Hille B, Lagrou C, Stehelin D, Montreuil J, Verbert A and Delannoy P (1992) The $c$-Ha-ras oncogene induces increased expression of $\beta$-galactoside $\alpha$-2,6-sialyltransferase in rat fibroblast (FR3T3) cells Glycobiology 2 49-56
Lloyd CW (1975) Sialic acid and the social behaviour of cells Biological Reviews $50325-350$

Morgenthaler J, Kemmner W and Brossmer R (1990) Sialic acid dependent cell adhesion to collagen IV correlates with in vivo tumorigenicity of the human colon carcinoma sublines HCT116, HCT116a and HCT116b Biochemical and Biophysical Research Communications 171 860-866

Morris JE and Potter SW (1984) A comparison of developmental changes in surface charge in mouse blastocysts and uterine epithelium using DEAE beads and dextran sulfate in vitro Developmental Biology 103 190-199

Mulholland J, Aplin JD, Hong L, Ayad S and Glasser SR (1992) Loss of type VI collagen from rat endometrial stroma during decidualisation Biology of Reproduction 46 1136-1143

Nilsson BO and Hjertén S (1982) Electrophoretic quantification of the changes in the average net negative surface charge density of mouse blastocysts implanting in vivo and in vitro Biology of Reproduction 27 485-493

Nilsson BO, Lindqvist I and Ronquist G (1973) Decreased surface charge of mouse blastocysts at implantation Experimental Cell Research 83 421-423

O'Shea JD, Kleinfeld RG and Morrow HA (1983) Ultrastructure of decidualization in the pseudopregnant rat American Journal of Anatomy 116 271-298

Parr MB and Parr EL (1989) The implantation reaction. In Biology of the Uterus (2nd Edn) pp 223-277 Eds WP Jollie and RM Wynn. Plenum Medical, New York

Parr MB, Tung HN and Parr EL (1986) The ultrastructure of the rat primary decidual zone American Journal of Anatomy 176 423-436

Psychoyos A (1973) Hormonal control of ovoimplantation Vitamins and Hormones 31 201-256

Regan CM (1991) Regulation of neural cell adhesion molecule sialylation state International Journal of Biochemistry 23 513-523

Roberts ISD, Jones CIP and Stoddart RW (1990) Lectin histochemistry of the mast cell: heterogeneity of rodent and human mast cell populations Histochemical Joumal 22 73-80

Sartor P (1980) Cell proliferation and decidual morphogenesis Progress in Reproductive Biology 7 115-124

Sata T, Roth J, Zuber C, Stamm B and Heitz PU (1991) Expression of alpha 2,6linked sialic acid residues in neoplastic but not in normal human colonic mucosa. A lectin-gold cytochemical study with Sambucus nigra and Maackia amurensis lectins American Journal of Pathology 139 1435-1448

Shibuya N, Goldstein IJ, Broekaert WF, Nsimba-Lubaki M, Peeters B and Peumans WJ (1987) The Elderberry (Sambucus nigra L.) bark lectin recognizes the Neu5Ac( $(2,6) \mathrm{Gal} / \mathrm{GalNAc}$ sequence Joumal of Biological Chemistry 262 1596-1601

Taatjes DJ and Roth J (1990) Selective loss of sialic acid from rat small intestinal epithelial cells during postnatal development: demonstration with lectin-gold techniques European Journal of Cell Biology 53 255-266

Taatjes DJ, Roth J, Peumans W and Goldstein IJ (1988) Elderberry bark lectingold techniques for the defection of Neu $5 \mathrm{Ac}(\boldsymbol{\alpha} 2,6) \mathrm{Gal} / \mathrm{GalNAc}$ sequences: applications and limitations Histochemical Joumal $20478-490$

Vandamme V, Cazlaris H, Le Marer N, Laudet V, Lagrou C, Verbert A and Delannoy P (1992) Comparison of sialyl- and $\alpha$-1,3-galactosyltransferase activity in NIH3T3 cells transformed with ras oncogene: increased $\beta$-galactoside $\alpha$-2,6-sialyl-transferase Biochimie 74 89-100

Wang W-C and Cummings RD (1988) The immobilised leukoagglutinin from the seeds of Maackia amurensis binds with high affinity to complex-type Asnlinked oligosaccharides containing terminal sialic acidlinked $\alpha-2,3$ to penultimate galactose residues Journal of Biological Chemistry $2634576-4585$

Wang XC, Smith TJ and Lau JTY (1990) Transcriptional regulation of the liver $\beta$ galactoside $\alpha 2,6$-sialyltransferase by glucocorticoids Joumal of Biological Chemistry 265 17849-17853

Welsh AO and Enders AC (1985) Light and electron microscopic examination of the mature decidual cells of the rat with emphasis on the antimesometrial decidua and its degeneration American Joumal of Anatomy 172 1-29

Welsh AO and Enders AC (1987) Trophoblast-decidual cell interactions and establishment of maternal blood circulation in the parietal yolk sac placenta of the rat Anatomical Record 217 203-219

Yang P, Yin X and Rutishauser U (1992) Intercellular space is affected by the polysialic acid content of NCAM Journal of Cell Biology 116 1497-1506 